高血圧症における高尿酸血症

\author{
朝日生命成人病研究所 \\ 関顕 田中 敏行 藤并 潤
}

\title{
HYPERURICEMIA IN HYPERTENSION
}

Akira SeKI, M.D., Toshiyuki Tanaka M.D. and Jun Fuju, M.D.

The Institute for Adult Diseases Asahi Life Foundation

\begin{abstract}
摡要 高血圧症そのるのの疗酸代譤に及ぼす影響を明らかにするため，合併症のない高血圧症患者を 対象とし，血清尿酸值および高疗酸血症の頻度を，対照と比較した，血清尿酸值の平均㧍よび高尿酸 血症 ( $8 \mathrm{mg} / \mathrm{dl}$ 以上) の頻度は, 対照群男性 ( 324 例) $6.36 \mathrm{mg} / \mathrm{dl}, 9.2 \%$ ，女性 (102例) $5.29 \mathrm{mg} / \mathrm{dl}$, $1.9 \%$ ，未治療高血王群男性（65例） $6.44 \mathrm{mg} / \mathrm{al} ， 13.8 \%$ ，女性（29例） $5.11 \mathrm{mg} / \mathrm{dl} ， 0 \%$ あ゙り，男女 とも甪群間に有意差はなかつた。これに比し，治療中高血任群では，男性 (54例) $6.97 \mathrm{mg} / \mathrm{dl} ， 25.9$ $\%$ ，女性（42例） $5.94 \mathrm{mg} / \mathrm{dl} ， 7.1 \%$ あ゙り，血清尿酸值は，男女とも対照群および末治療高血圧群に 比し有意に高く，また高尿酸血症の頻度も，男性で対照群に比し有意涪からた．さらに治療以外の 因子の影響を知るため，男性対照群拉よび未治療高血圧群について，年令，肥満度，耐䖨能，血清コ レステロール值と尿酸の関連性を梌討した。これら諸因子の尿酸に及ぼす影響には，両群間に差異は ない，両群とも，肥满者拈よび若年者で高い㥧向がみられた，血无値と尿酸の間には有意の関連はみ られなかつた．以上より，合併症のない高血王症患者に㨟いては，未治療例では血清冢酸值および高 尿酸血症の頻度に正常者と大きな差はなく，これらは高血圧そのわのよりも，むしろその他の因子， 特に降圧䠼治療により大きく影響されるものと結論した。
\end{abstract}

\section{I. 緒 言}

日常臨床上しばしば，高血圧症患者に高尿酸血 症の合併を見，また痛風関節炎発作に遭遇するこ とも希ではない。これまでにも高血圧症患者では 高尿酸血症の頻度が高いとする報告が多い,1) -5).

しかし後述する如き種タの問題点があり，高血王 症そのものが，血清尿酸值を上昇させているか不 かは，明確ではない，尿酸代謝に及湆す高血圧症 そのものの影響をより明確にするため，合併症の ない高血压症患者を対象として，治療中和よび末 治㞠患者と正常対照者の血清尿酸值および高尿酸

〔昭和 49 年 6 月 1 日受稿〕

本論文要旨性第70会日本䛻環器学会関東甲信越地 方会（1973年，東京）に却いて発表した。
血症の頻度を比較したささらに治療以外の因子の 影響を知るため，未治療高血圧症患者と正常対照 者について，年令，肥满度，耐粕能，血清コレス テロール值，血代值と血清尿酸值拉よび高尿酸血 症の頻度との関連性を検討した。

\section{II. 研究方法}

A) 対象

1）対照群： 当研究所人間ドックを昭和 47 年 1月より昭和48年 9 月までに受診した者は，男性 641名，女性181名であつた。このらち，年令30才 以上，70才未満で，既往に高血圧，痛風，尿路結 石, 関節痛発作, 脳卒中, 虚血性心疾患のい寸゙れ をも指摘されたことがなく，検查所見で，尿蛋 白陰性，血清尿素窒素25mg/d 婳，P S P (15分 
値) $25 \%$ 以上，収縮期血圧 $140 \mathrm{~mm} \mathrm{Hg}$ 未満，拡張期 血圧 $90 \mathrm{~mm} \mathrm{Hg}$ 未満の全条件を満した者は，男性 324 名，女性 102名であつた。これを正常対照群とし た. 平均年令は男性 47.8 才，女性 48.6 才であつ た.

2）高血圧群：当研究所外来を昭和 46 年 1 月 より，昭和48年 9 月までに受診し，諸検査を実施 乙得た 30 才以上 70 才未満の 高血圧症患者，男性 186名，女性 135 名と，人間ドック受診者のらち30 才以上70才未満で，既往に高血圧を指摘されたこ とのある者および受診時の血圧が収縮期 $140 \mathrm{~mm} \mathrm{Hg}$ 以上，または拡張期 $90 \mathrm{~mm} \mathrm{Hg}$ 以上であつた者，男性 228名，女性81名，計男性 414名，女性 216名を とりあげた。この中から，既往に痛風，尿路結 石，関節痛発作，脳卒中，虚血性心疾患のいずれ かを有する者，検查所見中尿蛋白陽性，血清尿素 窒素 $25 \mathrm{mg} / \mathrm{dl}$ 以上, P S P (15分値) $25 \%$ 未満, 眼 底所見Keith-Wagener 3 または 4 度のいずれかに 該当する者, さらに高血圧症の治療状況不明の 者，以前降圧剤を服用していたが受診時それを中 断していた者，および降圧剤を服用していないに もかかわらず収縮期血圧 $140 \mathrm{~mm} \mathrm{Hg}$ 未満かつ拡張期 血圧 $90 \mathrm{~mm} \mathrm{Hg}$ 未満の者等を除き，男性 238 名，女性 133名を得た。これを 3 群に分けた。（i）末治 療高血圧群；降圧剤治療を受けた経験がなく， 収縮期血圧 $150 \mathrm{~mm} H \mathrm{~g}$ 以上かつ拡張期血圧 $90 \mathrm{~mm} H \mathrm{Hg}$ 以 上の者，男性65名，女性29名.（ii）治療中高血 圧群; 受診時何らかの降圧剂を服用中の者. 男 性54名，女性42名.（iii）境界域血圧群; 降圧 剤治療の経験がなく，血圧值が（i）の条件を満 さない者. 男性 119名，女性62名.

高血圧群の血圧值は, 未治療高血圧群, 男性, 収縮期 $164.2 \pm 14.7 \mathrm{~mm} \mathrm{Hg}$ (平均值士標準偏差. 以 下同様)，拡張期 $101.0 \pm 7.8 \mathrm{~mm} \mathrm{Hg}$ ，女性 $165.2 \pm$ $11.9 \mathrm{~mm} \mathrm{Hg} ， \quad 100.4 \pm 8.7 \mathrm{~mm} \mathrm{Hg}$ ，治療中高血圧群， 男性 $156.0 \pm 23.3 \mathrm{~mm} H \mathrm{Hg} ， 96.5 \pm 9.6 \mathrm{~mm} \mathrm{Hg}$ ，女性 $155.8 \pm 19.6 \mathrm{~mm} \mathrm{Hg}, 95.5 \pm 10.9 \mathrm{~mm} \mathrm{Hg}$ であつた。

平均年令は未治療高血圧群，男性52.1才，女性 52.2 才, 治療中高血圧群, 男性53.9才, 女性 52.3
才であつた.

B) 方法

血清尿酸值は炭酸ソーダを用いる比色定量法 (Eichhorn $)^{6)}$ ，血清コレステロール值はZak-Henly 変法で測定した。糖負荷試験は，ブドウ糖50 g ま たは $100 \mathrm{~g}$ を経口投与し，血糖值を耳架血，glucose-oxidase法で測定した． 糖負荷試験の結果は, 日本糖尿病学会勧告による判定規準を用い, 正常 型, 境界型, 䌅尿病型に分類した．標準体重 $(\mathrm{kg})$ を $\{$ 身長 $(\mathrm{cm})-100\} \times 0.9 て ゙$ 算出し，これに 対する増減のパーセントをもつて肥満度を表現し た.

\section{III. 結 果}

\section{A ) 高血圧症患者の血清尿酸值および高尿酸血 症の頻度（図 1)}

高血圧症そのものの，血清尿酸值および高尿酸 血症の頻度に与える影響を知るため，正常対照群 と末治療高血圧群を比較した，さらに，治療によ る影響を検討するため，治療中高血圧群と正常対 照群および未治療高血圧群とを比較した。

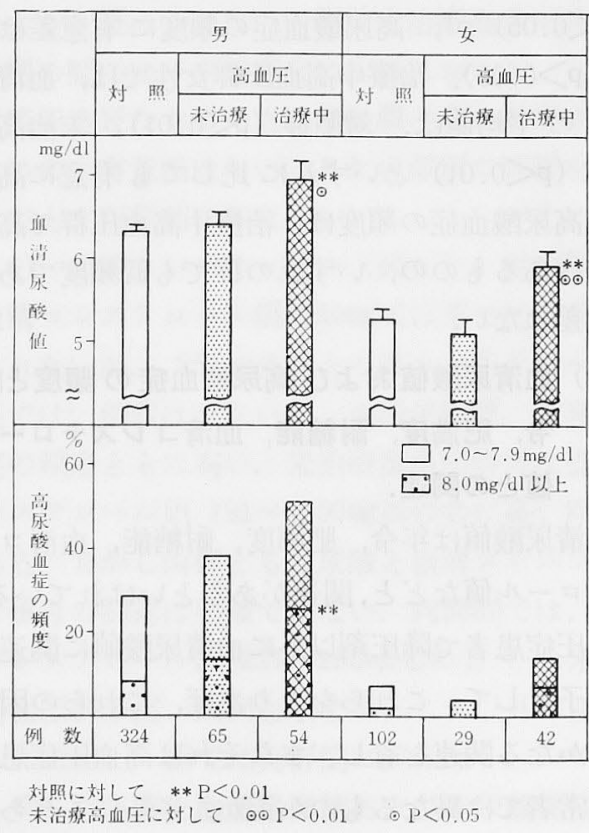

図 1．高血圧と尿酸 
対照群 の 血清尿酸値 は, 男性6. $36 \pm 1.22 \mathrm{mg} / \mathrm{dl}$ (平均值士標準偏差, 以下同様), 女性 $5.29 \pm 1.10$ mg/dlであり，血清尿酸值 7.0〜 7.9mg/dlの者は, 男性64例 $(19.7 \%)$ ，女性 8 例 $(7.8 \%)$ ，血清尿酸 值 $8.0 \mathrm{mg} / \mathrm{dl}$ 以上の者は, 男性30例 $(9.2 \%)$, 女性 2 例 $(1.9 \%)$ である.これに対し未治療高血圧 群では, 血清尿酸值の平均值士標準偏差, 7.0 $7.9 \mathrm{mg} / \mathrm{dl}$ 者の例数（\%),8.0mg/dl以上の者の例 数 (\%) はそれぞれ，男性 $6.44 \pm 1.33 \mathrm{mg} / \mathrm{dl} ， 16$ 例 $(24.6 \%), 9$ 例 $(13.8 \%)$, 女性 $5.11 \pm 1.01 \mathrm{mg} / \mathrm{dl}$, 1 例 $(3.4 \%) ， 0$ 例 (0\%) であり，未治療高血 圧群男性で, 高尿酸血症の頻度がやや高い傾向に あるものの, 男女いずれにおいても対照群との間 に有意差はない。治療中高血珐群では, 上述の 值はそれぞれ，男性6.97士1.04mg/dl，14例（25.9 $\%), 14$ 例 (25.9\%), 女性 5.94土1.31 mg/dl, 6 例 $(14.2 \%) ， 3$ 例 $(7.1 \%)$ である. 治療中高血纴 群男性では, 対照群に比し血清尿酸値の平均値 $(p<0.01)$, 血清尿酸値 $8.0 \mathrm{mg} / \mathrm{dl}$ 以上の者の頻度 （ $p<0.01 ）$ ともに有意に高い. また未治療高血 圧群と比較すると, 血清尿酸值の平均値は高い $(\mathrm{p}<0.05)$ が，高尿酸血症の頻度に 有意差はな い（p>0.05）. 治療中高血圧群女性では, 血清尿 酸值の平均值は, 対照群 $(p<0.01)$, 末治高血 圧群（p<0.01）といずれに比しても有意に高い が，高尿酸血症の頻度は，治療中高血圧群で高い 傾向はあるものの，いずれの群でも低頻度であり 有意差はない。

\section{B）血清尿酸值および 高尿酸血症の頻度よl年}

令, 肥満度, 耐糖能, 血清コレステロール 值との関連.

血清尿酸值は年令, 肥満度, 耐糖能, 血清コレ ステロール値などと,関連があるといはれている。 高血圧症患者で降圧剤以外に血清尿酸值に関連す る因子として，これらをとりあげ，これらの因子 はいかなる関連を有し, またそれは高血圧症患者 と正常者では異なるものか否か,さらにこれらの 因子を考虑したとき血清尿酸値は高血圧症患者と

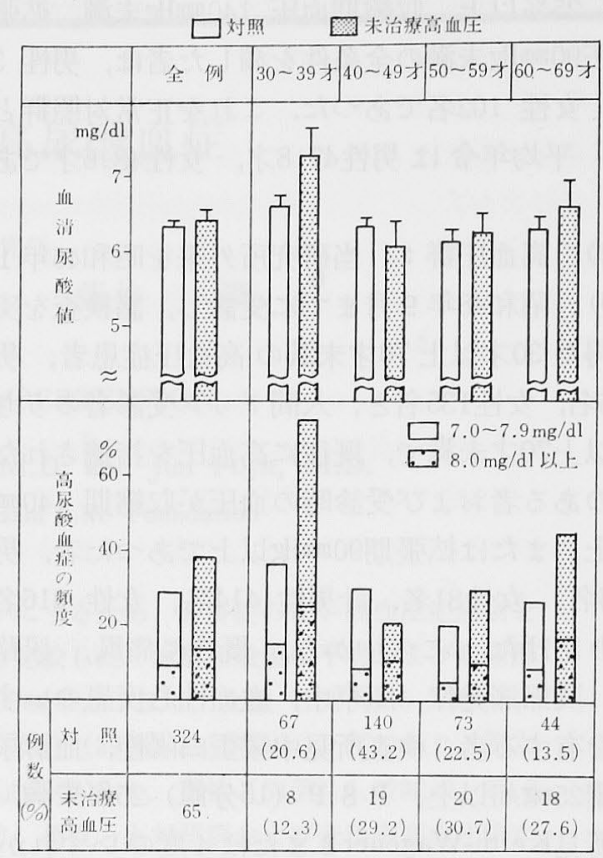

図2.年令と尿酸（男）

正常者で差があるか否かを明らかにするため，男 性対照群扎よび男性未治療高血圧群について検討 を行なつた。

1）年令（図 2）：対照群，未治療高血珐群 ともに，30才台で血清尿酸値が高い傾向がみられ た. 高尿酸血症の頻度も30才台で高い傾向があ り, 特に未治療高血圧群で血清尿酸值 $7.0 \sim 7.9$ $\mathrm{mg} / \mathrm{dl}$ の者の頻度が高い，しかし各年令別に対照群 と未治療高血圧群とを比較すると, 雨群間に差は ない。

2) 肥満（図 3 ）：対照群では肥満度が増すと ともに, 血清尿酸值, 高尿酸血症の頻度ともに增 加し, 肥満者 (肥満度 $+10 \%$ 以上) では, 非肥満 者 (肥満度+10\%未満) に比し有意に高い、未治 療高血圧群でも $+20 \%$ 以上の高度肥満者で，血清 尿酸值, 高尿酸血症の頻度ともに高いが，対照群 ほど肥満との関連は明膫ではない，各肥満度別に 対照群と末治療高血圧群を比較すると,いずれの 肥満度においても血清尿酸値, 高尿酸血症の頻度 


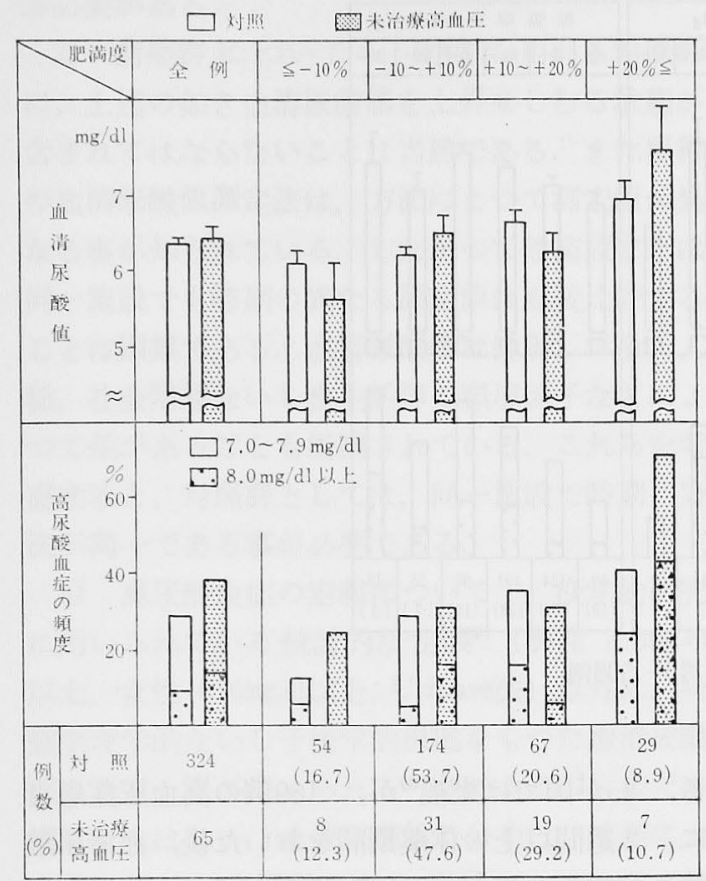

図3、肥満と尿酸（男）

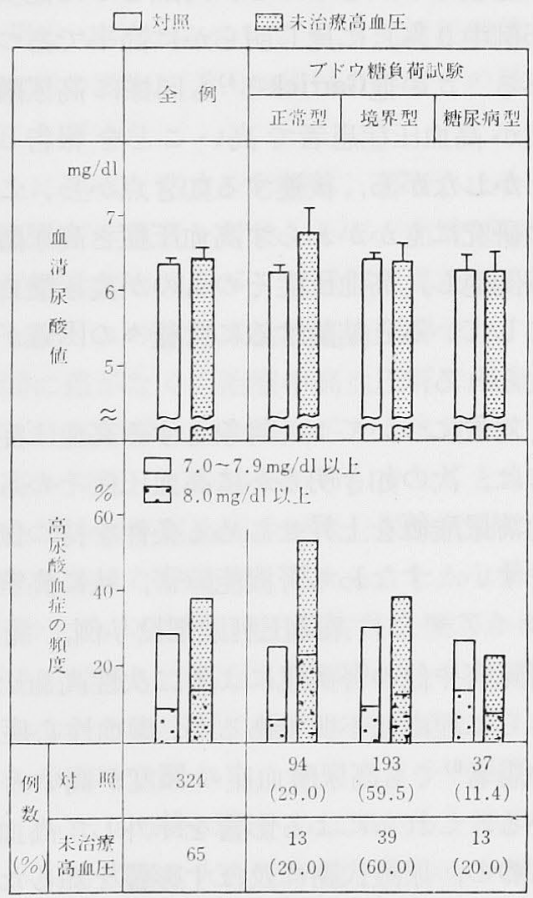

図 4. 耐煻能と尿酸（男）

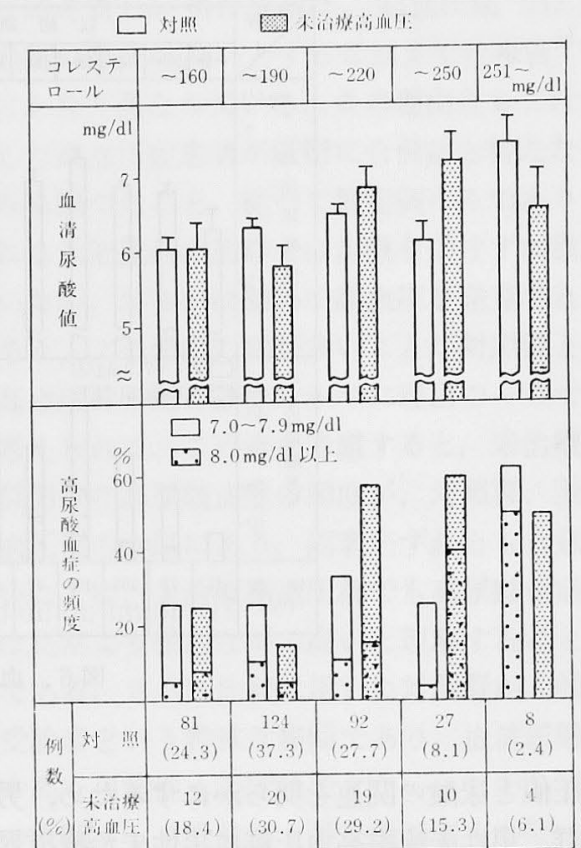

図 5。血清コレステロールと尿酸（男）

ともに, 両群間に明確な差はない。

3）耐糖能（図 4）：ブドウ糖負荷試験の成績 により 3 型に分けた. 対照, 未治療高血圧両群の 各型の間には，未治療高血圧群において，むしろ 耐糖能良好なもので血清尿酸値の高い傾向はある ものの，有意差はない。また各型別に両群を比較 しても，両群間に差はない。

4）血清コレステロール（図 5）：対照群では

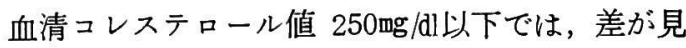
られないが，251mg/dl以上の高コレステロール血 症では，例数は少ないが，血清尿酸値，高尿酸血 症の頻度ともに高い未治療高血圧群では血清コ レステロール值 191〜 250mg/dlの者に高い傾向が ある. しかし両群とも，尿酸と血清コレステロー ル值との関連は明確ではない。両群間では, 血清 コレステロール值 221 250mg/dlの者で，未治療 高血左群が商い傾向を示すが，これ以外の血清コ レステロール值では両群間に差はない，

C) 血圧值と血清尿酸值およひ高尿酸血症の頻 度 (図 6 ) 


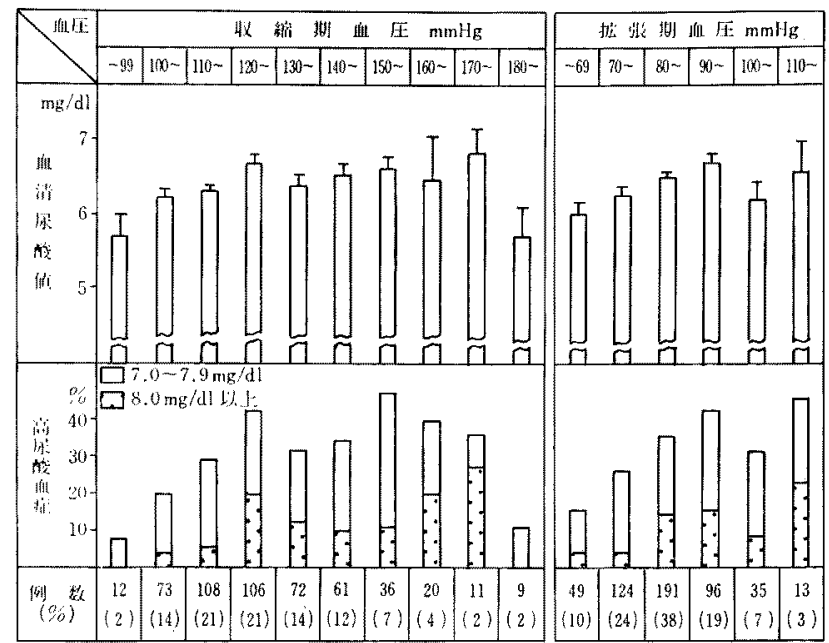

因6.血在上尿酸（男）508例

血圧值と尿酸の関連を明らかにするため，男性 対照群，男性未治療高血圧群に男性未治療境界域 血生群を加えた 508例につき，険討を加えた，図 6 に示す如く，収縮期および抎張期血王と，血清 尿酸值拉よび高尿酸血症の頻度の間には, 明確な 関連は見出し難い。

\section{IV. 考 案}

\section{A ）高血圧症における高尿酸血症の頻度}

これまで高血圧症では高尿酸血症の頻度が高い とする報告が多い，すなわちKinsey等 ${ }^{1}$ は，種々 の治療を受けた 400 例の高血圧症患者のうち40\% 以上が高尿酸血症（正常上限, 男性 $6 \mathrm{mg} / \mathrm{dl}$, 女性 $5 \mathrm{mg} / \mathrm{dl}$. 测定法記載なし) をしわすと述べ，また Breckenridge $\mathrm{e}^{23}$ は，治療中の高血生患者の58\%，末 治療のそれの $27 \%$ が高尿酸血症（正常上限 $7.0 \mathrm{mg}$ $/ \mathrm{dl}$, 女性 $6.0 \mathrm{mg} / \mathrm{dl}$. Folin変法) をしめし, これ は他の疫学的調查による高尿酸血症の頿度に比し はるかに高率であるとしている。 Cannonら は 217例の高血任症患者中 $47 \%$ か，高尿酸血症（47 例の正常者による正常上限, 男性 $6.4 \mathrm{mg} / \mathrm{dl}$, 女性 $5.9 \mathrm{mg} / \mathrm{dl}$. Brown法招よびUricase法) をしめし， このうち未治療, 血清尿素窒素值正常の高血圧症 患者でも26\%が高尿酸血症をしめすと報告してい
る. わが国では東福6)が，189例の高血圧症患者 に，2 週間以上の休薬期間を扮いた後，血清尿酸 値を測定し， $35 \% か ゙$ 高尿酸血症（7.0mg/al以上. 測定法記載なし）をしめし，対照とした他疾患々 者（36例中 $0 \%)$ に比し明らかに高率であつたと している.この他Garrickらも同栐に高尿酸血症 の頻度が高血圧症患者で高いことを報告してい る.しかしながら，後述する如き点から，これら 多くの研究にもかか放らず高血压症と高尿酸血症 が直接関連し，高血圧症そのものが高尿酸血症を あたらしていると結諭するには種々の困難がある と䠸えられる。

1）対象について：対象々する高血压症患者 の中には，次の如き明らかに高血王症そのもの以 外に血清尿酸值を上昇せしめる条件を持つ例が含 まれやすい。すなわち腎機能障害，特に高窒素血 症，サイアザイド系降圧利尿剂投与例，痛風に よる腎障害や他の腎挨患による二次性高血圧症な ど, さらに理由は不明であるが, 虚血性心疾患 ${ }^{7}$, 脳卒中患者 ${ }^{82}$ でも高氺酸血症の頻度が高いと言わ れている。これらによる影響を除外して高血王症 そのものの，尿酸代謝に及ぼす影響を知るために は，対象には合併症のない，末治療高血左症を選 
ぶ必要がある。

2）対照群について：比較に用いる対照群 に，上述の如き血清尿酸值を上昇せしむる状態が 含まれてはならないことは当然である。また現行 の血清尿酸値測定法は，方法によつて測定値が異 なる事が知られている、したがつて他施設または 同一施設でも時期の異なる測定値は直接比較する ことは困難である，血清尿酸值は性別，年令，人 種, 社会階層ない乙食生活等の環境因子などによ つて差があることる指摘されている。これらを考 慮すると，対照群としては，同一施設て時期，方 法が同一である事が必要である。

3）高尿酸血症の定義について：疫学的研究 に用いられている統計的な定義9（男性 $7.0 \mathrm{mg} / \mathrm{dl}$ 以上，女性 $6.0 \mathrm{mg} / \mathrm{dl}$ 以上, Uricase法）以外飞，病 態生理学的ないし予後学的根拠をるつた血清尿酸 值の正常上限が決められるべきであるが，未だ確 実なるのはない，血清尿酸値の分布は，性別によ り異なるが，高尿酸血症の定義も性別により異 なるべきか否かも明らかではない，そこで著者ら は，男女いずれについても，血清尿酸值 $7.0 〜$ $7.9 \mathrm{mg} / \mathrm{dl}$ 者と， $8.0 \mathrm{mg} / \mathrm{dl} 以 上 の$ 者との頻度を記 するにとどあた。

以上に述べた諸点を考慮し，著者らは合併症の ない高血圧症患者を対象として，血清尿酸梿执よ び高尿酸血症の頻度が，対照群と異なるか否かを 検討した.この結果末治療高血生群では，対照群 との間に差がなく，治療中高血圧群では血清尿酸 值叔よび高尿酸血症の頻度がともに対照に比し有 意に高かつた。この結果から，少なくとも合併症 をもたない軽症高血圧症では，尿酸代謝に正常者 と大きな差はないと考无られる。しかし降王昘治 療を受けている高血压症患者では，明らかに，尿酸 代謝が正常者とは異なる例が多いと考光られる。 服用している降生剂の種類以不明ではあるが，現 在のわが国の状況から，サイアザイド系降左利尿 楽が，かなりの例に朋いられていると推定され， これが尿酸代謝に大きな影響をもつ事を推論し得 る成績と考古られる。
今回著者らが得た成績は，高血圧症では高尿 酸血症の頻度が、高いとするこれまでの報告1) 5) と は，かなり異なつている。この理由としては対象 とした高血圧症患者が敩密に合併症を持たない者 のみに限つたこと，従つて軽症例のみであり，さ らには未治療高血王群では治療を受けずに放置し ていたか，あるいは初めて高血圧を発見された者 であり，より軽症の例が多いことが対照群と末治 療高血圧群の間に差のなかつた理由の一つである 亡考学られる.この点を考虑すると，未治療高血 王群男性の高尿酸血症の頻度が, 対照群, 治療中 高血生群の中間にあり，両者いずれとも有意差が ないことは，未治療高血圧群でも高尿酸血症の頻 度は正常より僅かながら高いと理解することも可 能である。さらに比較に用いた対照群が人間ドッ ク受診者といら特殊な集団であり，血清尿酸值が やや高い可能性も否定梳できい，しかし当研究 所の人間ドック受診者と外来受診者との間に, 生 活環境等に大きな差はないと考えられる.

以上に述べた点を考慮しても，合併症のない高 血王症では高尿酸血症の頻度は，正常者之大きな 差はなく，降王剤治療の影響がより大きいことを 結論し得ると考光た。

B）血清尿酸值 および高尿酸血症の頻度と年 令，肥満度，耐糖能，血清コレステロール 值との関連

1）年令：これまでの研究では，30才以上の 正常男子の血清尿酸值は，30才台で僅か心高い傾 向があるとする報告 ${ }^{103}$ はるものの，年令によつ て明らかな差はないとするすのが多い11212. 高血 压症患者では年令と関係がないとするもの地， 若年高血圧症患者でより高尿酸血症の頻度が高い とするもの52とがある．著者らの成績で30才台の 未治憭高血环症で，40才以上に比し，高尿酸血症 の頻度が高からた理由としては，対像が合併症を 持たない者のみであるので，若年者の群には，年 を経るに従い合欮症を生じてくるであるら，やゃ 重症の例を含み得るのに対し，高年者の群では発 症が荤いかをたは経過年数が長いにももかかわら 
ず合併症を来たしていない，より軽症例が多く含 まれている事る，午の一つであるとも洘えられる。

年令の血清尿酸に及ぼす影響は，正常群と高血 圧群で差はない。

2）肥满：血清尿酸值が，体重ないし種々の 計算法による肥満度と，正の相関をるつことは多

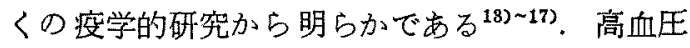
症患者で血清尿酸值と肥満との関連を述べたも のは少ないが，Garrick等》は関連はないとしてい、 る. 著者らの成績では，対照群では肥満度と血清 尿酸值就よび高尿酸血症の頻度は明らかな関連を 有している，未治療高血压症では，この傾向は中 や明確ではなくなるが，肥满度十 $20 \%$ 以上の高度 肥満者では，血清尿酸値および高尿酸血症の頻度 が高く，高血王症患者でも，正常者と同様，高度 肥満が血清尿酸值を上昇させる因子となつている と考えられる。

3）耐栯能：糖尿病と痛風，あるいは糖代謝 異常之高尿酸血症の関連については, 肥满が両者 を促進させる因子となっていることすあつて，古 くから多くの報告がある，当然両者の合併が多い とするるのが多いが, 一方, 大規模な調查の結 果, むしろ糖代謝異常之高尿酸血症は, 合併し難 心傾向にあるとする報告もある ${ }^{13) 183}$ ，高血圧症患 者について述べられたものはない，著者らの成績 でも，耐糖能と尿酸の間には，対照群でも未治 療高血圧群でも, 明らかな関連は見出し 難かつ た.

4）血清コレステロール䛧：正常者における 血清コレステロール值と血清尿酸值については， これまで多くの報告があり，相関ありとするすの

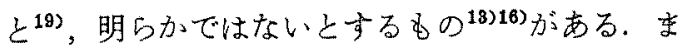
た高血圧症患者に帛いても，関連ありとするも

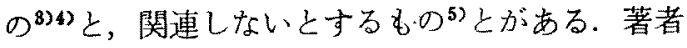
らの成績では, 対照群, 未治療高血正群ともに, 血清コレステロール值と尿酸は明確な関連を有す るとは言い難く，また，血清コレステロールの尿 酸に及ぽす影響が，両群間で異なるとは言い難か つた。
以上1)から4)に述べた如く，年令，肥満度，耐 糖能, 血清コレステロール值の血清尿酸值および 高尿酸血症の頻度に及活す影響は，対照群と未治 療高血压群とで，異なるものではないと考えられ た、またこれらの因子を考虑しても，雨群間に血 清尿酸值扣よび高尿酸血症の頻度に差はないと結 論し得た。

C) 血圧值と血清尿酸值および高尿酸血症の頻 度

疫学的研究では，血圧值と血清尿酸值の関連は 明確でないとするもの ${ }^{14)}$ ，高尿酸血症では高血圧 の頻度が高いとするもの ${ }^{17)}$ ，血清尿酸值が高くな るにつれ，血压の平均值が僅かながら上昇すると

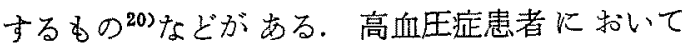
あ，血王值と関連ありとするすの离）なしとする

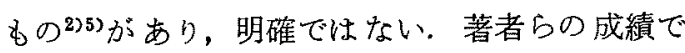
は，収縮期和よび拡張期血圧と尿酸との関連は明 確ではなく，この点も軽症高血圧症では，尿酸代 謝に正常と大きな差は存在しないのではないかと いら著者らの考兄の一つの根拠となり得る成績で あるらと考えられる。

\section{V. 結 論}

合併症のない高血厈症患者(未治療男性 65例， 女性 29例，治療中男性 54例，女性42例）上対照 (男性324例，女性102例)との，血清屎酸值，高尿 酸血症の頻度を比較した．さらに男性の対照群乱 よび未治療高血圧群で, 尿酸と年令, 肥満度, 耐 糖能, 血清コレステロール值, および血王值（境 界域血仕群を含む）との関連性を娭討した。

1）未治療高血圧群では，男性，女性之もに， 血清尿酸值扣よび高尿酸血症の頻度に対照群と有 意差はない。

2）治療中高血俚群では，男性，女性ともに， 血清尿酸値は, 対照群, 未治療高血圧群いずれに 対しても，有意に高い。高尿酸血症の頻度は，男 性では対照群に比し有意に高いが，女性では頻度 が低く, 有意差はない。

3）年令, 肥満度, 耐喏能, 血清コレステロー 儿值の尿酸に及ぼす影響怔，対照群，未治療高血 
区群で同様である.

4）対照群，未治療高血王群ともに，30才台の 者，および肥満者で，血清尿酸値および高尿酸血 症の頻度が高い傾向がある. 耐糖能および血清二 レステロール值と尿酸には，明確な関連はない，

5）血厈值し尿酸の間に明確な関璉は見出し難 い.

以上の点上り，合併症のない高血圧症患者に抽 いては，血清尿酸值および高尿酸血症の頉度は， 正常者に比し大きな差はなく，高血王以外の因 子，特に降圧剤治療により大きく影響される。こ のことは，日常の臨床上，注目すべきことと考え た.

\section{文献}

1) Kinsey, D., et al.: Incidence of hyperurice$\mathrm{mia}$ in 400 hypertensive patients. Circulation., 24: 972, 1961. - 2) Breckenridge, A.: Hypertension and hyperuricemia. Lancet, 1: 15, 1966. -3) Cannon, P.J. et al.: Hyperuricemia in primary and renal hypertension. New Engl. J. Med., 275: 457, 1966. 4) Garrick, R., et al.: Serum uric acid in normal and hypertensive australian subjects. From a continuing epidemiological survey on hypertension, commenced in 1955. Aust. N.Z.J. Med., 4: 351, 1972. -5) 東福要平, 高血压症の尿酸代謝買常に関士る研究。日督誌, $14: 485,1972$. -6) Eichhorn, F., et al.: Improvement of the uric acid determination by the carbonate method for serum and urine. J. clin. Pathol., 14: 450, 1961. - 7) London, M., et al.: Distribution patterns of uric acid in coronary artery disease. Clin. chem., 13: 132, 1967. - 8)
Pearce, J. et al.: Uric acid and plasma lipids in cerebrovascular disease. Part. 1. Prevalence of hyperuricaemia. Brit. Med. J., 4: 78, 1969. -9) Gresham, G.E.: Hyperuricemia. An epidemiologic review. Arch. Environ. Health., 11: 863, 1965. -10) 西岡久寿樹他: 血清尿酸値の疫学的研究, 臨 整外, $6: 855,1971$. - -11) Mikkelsen, W.M., et al.: The distribution of serum uric acid values in a population unselected as to gout or hyperuricemia. Tecumseh, Michigan, 1959-1960. Amer. J. Med., 39: 242, 1965. -12) 西沢常男：佋清打 よび尿中尿酸値知見補遗。附 ${ }^{15} \mathrm{~N}-$ グリシン・尿酸と りこみ㳊関与る研究，リウマチ，7:324，1967。一 13) Mikkelsen, W.M.: The possible association of hyperuricemia and/or gout with diabetes mellitus. Arthritis. Rheum., 8: 853, 1965. -14) Myers, A.R., et al.: The relationship of serum uric acid to risk factors in coronary heart disease. Amer. J. Med., 45: 520, 1968. -15) Acheson, R.M., et al.: New Haven survey of joint diseases. The prediction of serum uric acid in a general population. J. Chron. Dis., $21: 543,1969$. 16) Laing, J.K., et al.: Serum uric acid levels in New Zealanders. New Zealand Med. J., 78: 65, 1973. -17) Klein, R., et al.: Serum uric acid. Its relationship to coronary heart disease risk factors and cardiovascular disease, Evans Country, Geogia. Arch. intern. Med., 132: 401, 1973. -18) Herman, J.B., et al.: Diabetes prevalence and serum uric acid. Observations among 10,000 men in a survey of ischemic heart disease in Israel. Diabetes, 16: 858, $1967 .-19$ ) Schoenfeld, M.R., et al.: Serum cholesterol-uric acid correlation. Metabolism, 12: 714, 1963. 20) Hall, A.P.: Correlations among hyperuricemia, hypercholesterolemia, coronary disease and hypertension. Arthritis. Rheum, 8: 846, 1966. 